\title{
Pyoderma Gangrenosum Triggered by Acute Ischemia of Lower Extremity: A Case Report
}

\author{
Alt Ekstremitenin Akut İskemisi ile Tetiklenen Pyoderma Gangrenosum: Olgu Sunumu
}

\author{
Mehmet KALENDER ${ }^{1}$ \\ (D) 0000-0002-8984-4028 \\ Oğuz UĞUR ${ }^{2}$ \\ (D) 0000-0003-0433-4270 \\ Hayat GÖKMENGIL ${ }^{3}$ \\ (1) 0000-0002-7308-0887 \\ Okay Güven KARACA ${ }^{4}$ \\ (D) 0000-0002-7749-9706 \\ Meryem İlkay EREN KARANIS ${ }^{5}$ \\ (D) 0000-0002-1097-4592
}

\begin{abstract}
Pyoderma gangrenosum is a very rare condition of unclear etiology with an estimated incidence of 3 to 10 cases per million people per year. We report a case of pyoderma gangrenosum triggered by acute ischemia of lower extremity without a prior history. Seventyseven years old female patient was admitted to the emergency department with necrosis on the anterior side of her left limb. Digital subtraction arteriography revealed total occlusion of the left common femoral artery for which thrombectomy under local anesthesia was performed successfully. The necrotic area was debrided and biopsies were obtained. Pathological examination revealed pyoderma gangrenosum and steroid treatment was began. The patient was discharged on the $10^{\text {th }}$ postoperative day with prednisone $48 \mathrm{mg}$ per day for the following 30 days. During the management of ischemic peripheral artery disease patients with persistent skin findings, pyoderma gangrenosum should be in the list of differential diagnoses.

Keywords: Pyoderma gangrenosum; risk factors; wound healing.
\end{abstract}

ÖZ

Piyoderma gangrenozum, tahmini insidansı yılda milyon kişi başına 3 ila 10 vaka olan, etiyolojisi açıklanamamış çok nadir görülen bir durumdur. Alt ekstremitenin akut iskemisi ile tetiklenen, daha önce öyküsü olmayan bir pyoderma gangrenozum vakası bildiriyoruz. Yetmiş yedi yaşında kadın hasta acil servise sol alt ekstremite anteriyor yüzde nekrotik yara ile başvurdu. Digital subtraction arteriography ile total tıkalı olduğu saptanan sol ana femoral artere lokal anestezi altında başarılı bir şekilde thrombektomi uygulandı. Nekrotik alan debride edildi ve biyopsiler alındı. Patolojik incelemede pyoderma gangrenozum saptandı ve steroid tedavisi başlandı. Hasta postoperative 10 . günde 30 gün boyunca günlük $48 \mathrm{mg}$ prednisone tedavisi ile taburcu edildi. Sebat eden cilt lezyonlu iskemik perifer arter hastalığ hastaların tedavisi sırasında, piyoderma gangrenozum ayırıcı tanılar listesinde bulunmalıdır. Anahtar kelimeler: Piyoderma gangrenozum; risk faktörleri; yara iyileşmesi.

\section{INTRODUCTION}

Pyoderma gangrenosum (PG) is a very rare condition with an unclear etiology with an estimated incidence of 3 to 10 cases per million people per year and characterized by aseptic dense infiltration of neutrophils into the epidermis, dermis or both (1). It may be associated with systemic diseases (2). The diagnosis is made by excluding other causes of cutaneous ulcerations with similar appearance including infection, malignancy, vasculitis, collagen vascular diseases, diabetes, and trauma. Pathergy based new ulcerations may be seen after trauma or injury to the skin. We report a case with PG triggered by acute ischemia of lower extremity without a prior history.

\section{CASE REPORT}

Seventy-seven years old female patient was admitted to emergency department with necrosis on the anterior side of her left limb. Medical history revealed prominent pain for the last 20 days and necrosis was first seen 2 weeks ago. Initial physical 
on the left limb. Right limb arterial pulses were palpable. Digital subtraction arteriography revealed total occlusion of the left common femoral artery. Laboratory findings were normal. The patient had sinusal cardiac rhythm on electrocardiography. Transthoracic echocardiography findings were normal. After taking patient's informed consent for both operation and publishing, left common femoral artery thrombectomy under local anesthesia was performed sucessfully. Massive hemorrhage occurred from the necrotic site on the first postoperative day; surgical haemostasis was done emergently, necrotic area was debrided and tissue biopsies were obtained. The patient was consulted with plastic and reconstructive surgery department. Postoperative medical treatment included antithrombotic and anticoagulant therapies. The wound was dressed postoperatively with Chlorhexidine Acetate BP $0.5 \%$ in white soft paraffin BP. The debridement material was macroscopically brown in color with partial necrotic appearance. On microscopic examination, the epidermis was ulcerated; dense inflammatory infiltration and coagulation necrosis were observed in the dermis and subcutaneous tissue. Inflammatory infiltration consisted of neutrophils, lymphocytes, and histiocytes. The biopsy specimen was evaluated in accordance with PG (Figure 1). Prednisone $48 \mathrm{mg} /$ daily was added to the treatment. The patient was discharged on the 10th postoperative day and was treated with prednisone $48 \mathrm{mg}$ per day for the following 30 days (Figure 2).

\section{DISCUSSION}

PG is an uncommon, ulcerative skin condition of unclear etiology. The disease was first described in 1930 with unusual skin eruption (3). There are several subtypes of PG according to lesions such as bullous (atypical) PG, pustular PG, vegetative PG and ulcerative (classic) PG which represents the majority of cases like our patient (1). PG is a diagnosis of exclusion. Simsek et al. (4) well described differential diagnosis of the disease and stressed he need to follow a thorough diagnostic evaluation including careful data collection of medical history, awareness of characteristic features on physical examination, obtaining a skin biopsy for not only histopathological purposes but also for tissue culture, and performing laboratory investigations aiming to rule out the diagnosis that mimic PG. Paralel to Simsek et al. (4), Neill et al. (5) reported to challenges to diagnosis and described " $5 \mathrm{p}$ " for aiding to reach conclusion. Misdiagnosis of skin ulcers as PG can occur up to $10 \%$ according to the literature $(6,7)$. In our case, we thought that arterial occlusion triggered the process and the wound was due to ischemia; but the biopsy results revealed the definitive diagnosis. Although varying degree (17\%-74\%) of associated diseases have been described in the literature (8) and the most commonly associated disorders were inflammatory bowel disease arthropathies and hematologic disorders such as paraproteinemia (9-11), our case did not have any associated diseases.

There is a lack of any definitive guidelines for the treatment of PG. Usually, a combination of topical and systemic suppression of inflammatory process and wound care were suggested for optimizing healing. Treatment options can be summarized in 3 topics; 1) Wounds should be cared gently to promote a moist environment and a

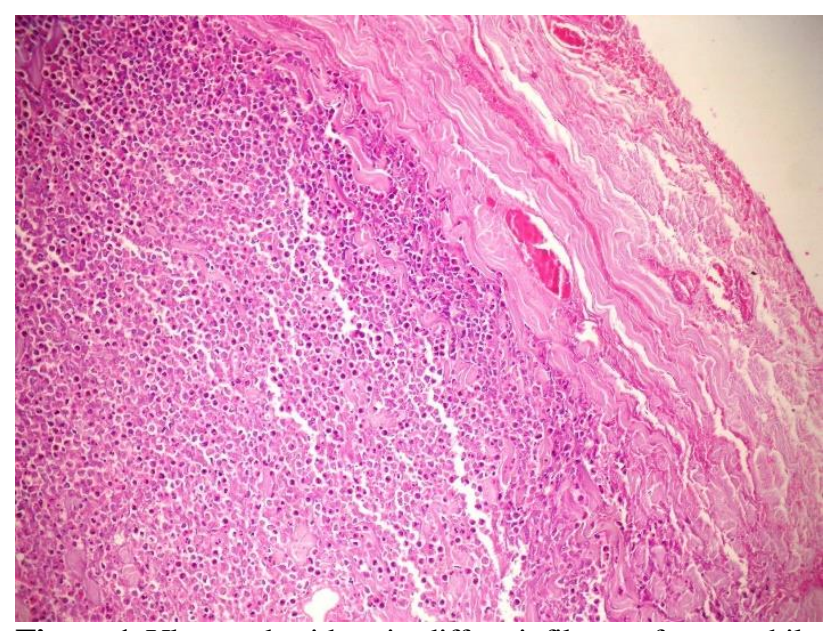

Figure 1. Ulcerated epidermis, diffuse infiltrate of neutrophils, lymphocytes, and histiocytes in the dermis. HEx 200

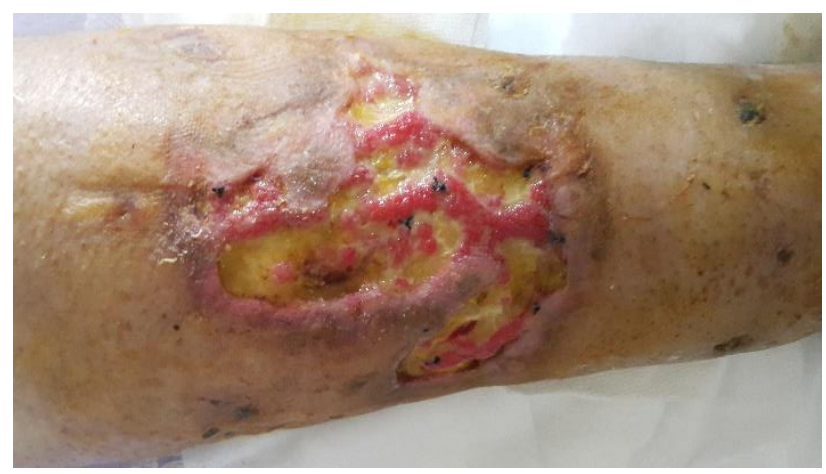

Figure 2. Postoperative first-month control

non-adherent dressing should be preferred. Due to pathergy risk, surgery for wound management in PG is in the grey zone. In our case, we preferred Chlorhexidine Acetate BP $0.5 \%$ in white soft paraffin BP. 2) Medical treatment options are local steroids, local calcineurin inhibitors, systemic steroids, intravenous immunoglobulin, systemic cyclosporine. Basically, lesion severity and resistance to recovery force clinician to choose a treatment option. Lack of efficient data and guideline for treatment is challenging the clinicians. We preferred systemic prednisone 48 $\mathrm{mg}$ /daily tapered and stopped at the30th day and complete healing achieved. 3) Pain management is required for most of the patients. Usually, pain may improve with treatment and some patients may require narcotic analgesics.

Bennett et al. (12) reported complete remission at 11.5 \pm 11.1 months in patients with classic PG and $9 \pm 13.7$ months in patients with bullous PG. Saracino et. al. (13) reported complete ulcer healing within 6 months. But this study had a limitation with follow-up. Only $46 \%$ of the patients were available to follow up for 6 months and 6 of 12 patients had complete ulcer healing in this study.

\section{CONCLUSION}

PG represents a diagnostic challenge which requires many specialists to be involved. During the management of ischemic peripheral artery disease patients with persistent skin findings, PG should be in the list of differential diagnosis. 


\section{REFERENCES}

1. Ruocco E, Sangiuliano S, Gravina AG, Miranda A, Nicoletti G. Pyoderma gangrenosum: an updated review. J Eur Acad Dermatol Venereol. 2009;23(9):1008-17.

2. DeFilippis EM, Feldman SR, Huang WW. The genetics of pyoderma gangrenosum and implications for treatment: a systematic review. Br J Dermatol. 2015;172(6):1487-97.

3. Inan I, Myers PO, Braun R, Hagen M. E, Morel P. Pyoderma gangrenosum after totally implanted central venous access device insertion. World J Surg Oncol. 2008;6:31.

4. Simsek S, van den Haak RF, Voskuyl AE, Rauwerda JA, Strack van Schijndel RJ. Symmetrical, painful ulceration of the lower limbs in a vascular surgery ward: a diagnostic challenge Pyoderma gangrenosum associated with IgG-kappa paraproteinaemia. Neth J Med. 2004;62(5):168-71.

5. Neill BC, Seger EW, Hooton TA, Bailey G, Rajpara A, Stoecker WV. The 5 P's of pyoderma gangrenosum. J Drugs Dermatol. 2019;18(12):1282-3.

6. Weenig RH, Davis MD, Dahl PR, Su WP. Skin ulcers misdiagnosed as pyoderma gangrenosum. N Engl J Med. 2002;347(18):1412-8.

7. Nguyen KH, Miller JJ, Helm KF. Case reports and a review of the literature on ulcers mimicking pyoderma gangrenosum. Int J Dermatol. 2003;42(2):84-94.

8. Bryan CS. Fatal pyoderma gangrenosum with pathergy after coronary artery bypass grafting. Tex Heart Inst J. 2012;39(6):894-7.

9. Thomas CY Jr, Crouch JA, Guastello J. Hyperbaric oxygen therapy for pyoderma gangrenosum. Arch Dermatol. 1974;110(3):445-6.

10. Davis JC, Landeen JM, Levine RA. Pyoderma gangrenosum: skin grafting after preparation with hyperbaric oxygen. Plast Reconstr Surg. 1987;79(2):200-7.

11. Mazokopakis EE, Kofteridis DP, Pateromihelaki AT, Vytiniotis SD, Karastergiou PG. Improvement of ulcerative pyoderma gangrenosum with hyperbaric oxygen therapy. Dermatol Ther. 2011;24(1):134-6.

12. Bennett ML, Jackson JM, Jorizzo JL, Fleischer AB Jr, White WL, Callen JP. Pyoderma gangrenosum. A comparison of typical and atypical forms with an emphasis on time to remission. Case review of 86 patients from 2 institutions. Medicine (Baltimore). 2000;79(1):37-46.

13. Saracino A, Kelly R, Liew D, Chong A. Pyoderma gangrenosum requiring inpatient management: a report of 26 cases with follow up. Australas J Dermatol. 2011;52(3):218-21. 